\title{
Synthesis of dental matrix proteins and viability of odontoblast-like cells irradiated with blue LED
}

\author{
Juliana Rosa Luiz Alonso $^{1}$ - Ana Paula Silveira Turrioni ${ }^{1}$ - Fernanda Gonçalves Basso ${ }^{1}$. \\ Carlos Alberto de Souza Costa ${ }^{2}$ • Josimeri Hebling ${ }^{1,3}$
}

Received: 1 May 2015 / Accepted: 19 January 2016/Published online: 12 February 2016

(C) Springer-Verlag London 2016

\begin{abstract}
To evaluate the effect of irradiation with lightemitting diode (LED; $455 \mathrm{~nm}$ ) on the viability and synthesis of dentin matrix proteins by odontoblast-like cells, MDPC-23 cells were cultivated $\left(10^{4} \mathrm{cells} / \mathrm{cm}^{2}\right)$ in 24 -well culture plates. After $12 \mathrm{~h}$ incubation in Dulbecco's modified Eagle's medium (DMEM), the cells were submitted to nutritional restriction by means of reducing the concentration of fetal bovine serum (FBS) for an additional $12 \mathrm{~h}$. Cells were irradiated one single time with one of the following energy densities (EDs): 0.5, 2, 4,10 , or $15 \mathrm{~J} / \mathrm{cm}^{2}$ and irradiance fixed at $20 \mathrm{~mW} / \mathrm{cm}^{2}$. Nonirradiated cells served as control. After $72 \mathrm{~h}$, cells were evaluated with regard to viability (methylthiazol tetrazolium technique (MTT)), mineralization nodule (MN) formation, total
\end{abstract}

Josimeri Hebling

jhebling@foar.unesp.br

Juliana Rosa Luiz Alonso

julianarlalonso@gmail.com

Ana Paula Silveira Turrioni

pops_turrioni@yahoo.com.br

Fernanda Gonçalves Basso

fergbasso@gmail.com

Carlos Alberto de Souza Costa

casouzac@foar.unesp.br

1 Department of Pediatric Dentistry and Orthodontics, School of Dentistry at Araraquara, Universidade Estadual Paulista-UNESP, Rua Humaitá, 1680, Araraquara, São Paulo, Brazil 14801-903

2 Department of Physiology and Pathology, School of Dentistry at Araraquara, Universidade Estadual Paulista-UNESP, Rua Humaitá, 1680, Araraquara, São Paulo, Brazil 14801-903

3 Departamento de Clínica Infantil, Faculdade de Odontologia de Araraquara, Rua Humaitá, 1680, Araraquara, Brazil 14801-903 protein (TP) production, alkaline phosphatase activity (ALP), and collagen synthesis (Sircol), $n=8$. The data were submitted to Kruskal-Wallis and Mann-Whitney tests $(p>0.05)$. There was no statistical difference between the viability of cells irradiated or not (control), for all the EDs. However, an increase in TP was observed for all the EDs when compared with the control group. A reduced ALP activity was seen in all irradiated groups, except for the ED of $0.5 \mathrm{~J} / \mathrm{cm}^{2}$, which did not differ from the control. There was no difference between the irradiated groups and control regarding collagen synthesis, with the exception of the ED of $10 \mathrm{~J} / \mathrm{cm}^{2}$, which inhibited this cell function. Significant reduction in MN occurred only for the EDs of 0.5 and $2 \mathrm{~J} / \mathrm{cm}^{2}$. The single irradiation with blue LED (455 nm), irradiance of $20 \mathrm{~mW} /$ $\mathrm{cm}^{2}$, and energy densities ranging from 0.5 to $15 \mathrm{~J} / \mathrm{cm}^{2}$ exerted no effective biostimulatory capacity on odontoblastlike cells.

Keyword Phototherapy · Light · Odontoblasts · Light-emitting diode

\section{Introduction}

Concern about the negative effects of restorative procedures on the dentin-pulp complex has intensified the search for materials and techniques with the purpose of stimulating pulp repair [1]. Some of the materials used in restorative dentistry not only exert no biostimulatory action on pulp tissue but also present a certain level of toxicity to its cells [2, 3]. Based on that premise, there is still the need for the development of new materials and techniques that favor the repair of the dentinpulp complex after caries removal and cavity preparation yet without promoting further cell death and tissue loss as seen for calcium-hydroxide-based materials. 
Photobiomodulation has been extensively studied in in vitro and in vivo experimental designs, as a treatment for several diseases $[4,5]$. Positive results have been demonstrated after the irradiation of fibroblasts, osteoblasts, rat muscle cells, and human epithelial cells with light-emitting diodes (LEDs) [6-8]. In view of these evidences, one could speculate that LED could also biostimulate pulp cells and thus favor pulp repair [9].

Some studies about the therapeutic action of light, in particular that of the blue spectrum $(400-500 \mathrm{~nm})$, have demonstrated an increase in the mitochondrial activity of human keratinocytes [10] and gingival fibroblasts [11]. However, little is known about the effects of the blue light on pulp cells $[11,12]$. Blue light is routinely used in restorative procedures for the photoactivation of resin-based materials, such as restorative resins, resin cements, adhesive systems, and resinmodified glass ionomer cements. If this same light source was capable of positively interfering with pulp tissue response and its repair mechanism, it could be used as a therapeutic adjuvant during restorative procedures for that specific purpose.

Odontoblasts play an important role in pulp tissue homeostasis and reparative processes $[13,14]$. Since these cells are organized in a single layer covering the internal surface of coronal and radicular dentin, they are the first cells injured by the harmful effects generated during the restorative procedures. The evaluation of the capacity of blue LED to exert some biostimulatory effect on odontoblast-like cells is of great importance to initially determine the feasibility of this therapy and also to establish specific parameters that would be capable of promoting this biostimulation. Therefore, the aim of this study was to evaluate the effects of irradiation with blue LED $(455 \mathrm{~nm})$ at different energy densities, on the viability of odontoblast-like cells, and the synthesis of typical dentin matrix proteins by these cells. The null hypothesis tested was that odontoblast-like cells do not respond to the irradiation with blue LED producing more pulp repair-related proteins.

\section{Methods and materials}

Immortalized cells of odontoblastic lineage isolated from rat dental papilla (MDPC-23) were cultivated in Dulbecco's modified Eagle's medium (DMEM; Gibco, Grand Island, NY, USA) culture medium, containing $10 \%$ fetal bovine serum (FBS; Gibco), $100 \mathrm{IU} / \mathrm{mL}$ penicillin, $100 \mu \mathrm{g} / \mathrm{mL}$ streptomycin, and $2 \mathrm{mmol} / \mathrm{L}$ glutamin (Gibco), until an adequate number of cells were obtained to conduct this study. Confirmation of odontoblastic phenotype is very important to ensure that cells maintain its phenotype through passages. Thus, before each experiment, cells are thawed and odontoblastic phenotype is confirmed by evaluation of alkaline phosphatase activity (ALP) activity and mineral nodule formation. The cells were seeded $\left(10^{4}\right.$ cells $\left./ \mathrm{cm}^{2}\right)$ in 24-well culture plates and incubated in a humid atmosphere with $5 \% \mathrm{CO}_{2}$ and $95 \%$ air, at $37{ }^{\circ} \mathrm{C}$ for $12 \mathrm{~h}$. After this period, the DMEM was aspirated and a new DMEM supplemented with only $0.5 \%$ FBS was kept in contact with the cells for additional $12 \mathrm{~h}$, with the purpose of promoting cellular stress due to nutritional deficit $[15,16]$. Immediately before beginning irradiation, this culture medium was replaced with a phosphate-buffered saline (PBS) solution. This was done because a measurement performed with a transmittance spectrograph USB2000 (Ocean Optics, San Diego, CA, USA), with an interface elaborated in the software program Lab View, revealed a high coefficient of absorption of the dye present in the DMEM (over $5 \%$ ) for irradiation at the wavelength of $455 \mathrm{~nm}$.

For irradiation of the MDPC-23 cells, a LED table [9] device was used, which had 24 diodes of the indium gallium nitride (InGaN) type, which emits light in the wavelength established at $455 \mathrm{~nm}$. When activated, each diode emits a light that irradiates individually at the base of each well of the culture plate in which the cells were cultivated. In this study, the irradiance (power density) emitted was established at $20 \mathrm{~mW} / \mathrm{cm}^{2}$ [17]. The total irradiation power was dosed, taking into consideration the loss of optical power due to the presence of the acrylic at the base of the wells in the plates.

The energy densities (EDs) selected for this study were 0.5 , $2,4,10$, and $15 \mathrm{~J} / \mathrm{cm}^{2}$, according to previous researches conducted in different types of cells $[6,11,12,18-24]$. Since the time of irradiation varied according to the $\mathrm{ED}$, due to the fact that the irradiance was fixed, a corresponding control group was delineated for each ED (Table 1), in which the cells were kept out of the incubator for the same period of time than the corresponding irradiated group. For the control groups, the same sample manipulation procedures were performed, including the positioning of the cells on the LED table; however, the diodes were not activated. Immediately after proceeding with the single irradiation of the cells, the PBS was replaced with a new culture medium supplemented with $0.5 \%$ FBS. Cell viability, total protein production, alkaline phosphatase activity, and collagen synthesis were performed 3 days after irradiation, while for the formation of mineralized nodules' assay, the cells were maintained for 7 days in culture prior the analysis. The " $n$ " represents the number of samples for each group (number of replicates), according to each methodology. Each test was repeated two times, in duplicate.

\section{Cell viability analysis (MTT assay)}

For this evaluation, the methylthiazol tetrazolium technique (MTT assay) was used, which determines the activity of the succinate dehydrogenase enzyme produced by the mitochondria present in the cells. For this purpose, $900 \mu \mathrm{L}$ of culture medium (DMEM) associated with $100 \mu \mathrm{L}$ MTT solution (Sigma-Aldrich, St Louis, MO, USA; $5 \mathrm{mg} / \mathrm{mL}$ in PBS) was 
Table 1 Physical parameters of LED and irradiation time according to energy doses (EDs)

\begin{tabular}{lllllll}
\hline Type of diode & Irradiance & Wavelength & Energy densities $\left(\mathrm{J} / \mathrm{cm}^{2}\right)$ & \\
\hline InGaN (indium, gallium, and nitride) & $20 \mathrm{~mW} / \mathrm{cm}^{2}$ & $455 \mathrm{~nm}$ & 0.5 & 2 & 4 & 10 \\
& Irradiation time & & $25 \mathrm{~s}$ & 1 min $40 \mathrm{~s}$ & $3 \mathrm{~min} 20 \mathrm{~s}$ & $8 \mathrm{~min} 20 \mathrm{~s}$ \\
\end{tabular}

applied on the cells, and these were incubated in a humidified oven at a temperature of $37^{\circ} \mathrm{C}$ for $4 \mathrm{~h}$. After this, the MTT solution was aspirated and replaced by $700 \mu \mathrm{L}$ of the acidified isopropanol solution $(0.04 \mathrm{~N} \mathrm{HCl})$, to dissolve the formazan crystals resulting from the cleavage of the methylthiazol tetrazolium salt by the succinate dehydrogenase enzyme of the viable cell mitochondria. Three aliquots of $100 \mu \mathrm{L}$ from each well were transferred to a 96-well plate (Costar Corp., Cambridge, MA, USA). Cell viability was evaluated at 570$\mathrm{nm}$ wavelength in an enzyme-linked immunosorbent assay (ELISA) reader (Thermo Plate, Nanshan District, Shenzhen, China).

\section{Total protein production}

Total protein production was performed in accordance with the Read and Northcote [25] protocol, which has been used in various cell irradiation studies [26, 27]. Cell lysis was performed by adding $1.0 \mathrm{~mL}$ of $1 \%$ sodium lauryl sulfate (Sigma-Aldrich), at room temperature, for $40 \mathrm{~min}$. The samples were then homogenized and $1 \mathrm{~mL}$ of Lowry reagent solution (Sigma-Aldrich) was added to all the samples, which were incubated at ambient temperature for $20 \mathrm{~min}$, followed by the addition of $500 \mu \mathrm{L}$ of Folin's solution and Ciocalteu's phenol reagent (Sigma-Aldrich), and then maintained for $30 \mathrm{~min}$. Three aliquots of $100 \mu \mathrm{L}$ were transferred to a 96well plate and submitted to absorbance analysis at $655 \mathrm{~nm}$ in an ELISA reader (Thermo Plate, Nanshan District, Shenzhen, China). The total protein dosage $(n=8)$ was calculated by means of a standard curve, containing known concentrations of bovine albumin (Sigma-Aldrich). The mean readout for the three aliquots was computed and the data used in statistical analysis.

\section{Alkaline phosphatase activity}

Alkaline phosphatase activity was determined according to the protocol of the Alkaline Phosphatase Kit (Labtest Diagnóstico S.A., Lagoa Santa, MG, Brazil). This assay was originally developed for pure plasma evaluation; however, it has been adapted for in vitro studies as a method to evaluate ALP activity of odontoblast-like cells, osteoblasts, and other types of cells, demonstrating the feasibility of this method for in vitro cellular analysis [28]. In the same way as for the quantification of total protein, the cells were lysed in $1.0 \mathrm{~mL}$ of $1 \%$ sodium lauryl sulfate (Sigma-Aldrich), at room temperature, for $40 \mathrm{~min}$. Fifty microliters of substrate $(22 \mathrm{mmol} /$ L) sodium thymol-phthalein monophosphate and $500 \mu \mathrm{L}$ of buffer solution $(300 \mathrm{mmol} / \mathrm{L}$, $\mathrm{pH} 10.1)$ were added in tubes, followed by incubation in water bath at $37^{\circ} \mathrm{C}$ for $2 \mathrm{~min}$. Next, $50 \mu \mathrm{L}$ of each sample were added, which were incubated for $10 \mathrm{~min}$. After this period, $2 \mathrm{~mL}$ of color reagent $(94 \mathrm{mmol} / \mathrm{L}$ sodium carbonate and $250 \mathrm{mmol} / \mathrm{L}$ sodium hydroxide) was added. The absorbance of the samples was determined in a spectrophotometer (Thermal Plate) at the wavelength of $590 \mathrm{~nm}$. Alkaline phosphatase activity $(n=8)$ was calculated using the standard curve with known concentrations of ALP and normalized by the total protein values found in each sample.

\section{Collage synthesis assay (Sircol red)}

Collagen synthesis analysis was performed using the colorimetric SIRCOL Collagen Assay Kit (Biocolor, County Antrim, Northern Ireland, UK), in accordance with the manufacturer's recommendations. Succinctly, $1 \mathrm{~mL}$ of Sircol red was added to each $100-\mu \mathrm{L}$ fraction of the sample solution, followed by incubation for $1 \mathrm{~h}$ under agitation at $450 \mathrm{rpm}$ (Thermomixer comfort-Eppendorf AG, Hamburg, Germany). The samples were centrifuged at 12,000 rpm for $10 \mathrm{~min}$, and the supernatant was discarded. Immediately afterward, $750 \mu \mathrm{L}$ of ice-cold acid-salt wash reagent solution was applied, in order to wash the samples and eliminate unspecific aggregations. The samples were centrifuged again at $12,000 \mathrm{rpm}$ for $10 \mathrm{~min}$. After this period, $1 \mathrm{~mL}$ of alkali reagent was added in order to solubilize the pellet formed. After complete solubilization, $100 \mu \mathrm{L}$ of the solution was collected and plated in triplicate in a 96-well plate for readout in a spectrophotometer at $555 \mathrm{~nm}$ (Thermo Plate). The collagen concentration of each sample was determined by means of a standard curve with pre-determined concentrations of collagen.

\section{Mineralization nodule formation (alizarin red test)}

For this protocol, the cells were maintained in culture medium containing $10 \mathrm{mM} \beta$-glycerophosphate, and $2 \mathrm{mM}$ ascorbic acid (Sigma-Aldrich), supplemented with $0.5 \%$ FBS. The analysis was done on the seventh day of culture, after the irradiation. For this purpose, the cells were fixed in $70 \%$ 
ethanol for $1 \mathrm{~h}$ and afterwards washed with distilled water for $5 \mathrm{~min}$. Next, the alizarin red (Sigma-Aldrich) solution was added, which was maintained under agitation for $20 \mathrm{~min}$. The samples were then washed twice with distilled water for $5 \mathrm{~min}$ and were submitted to quantitative analysis by means of solubilization of the nodules. For this purpose, $1 \mathrm{~mL}$ cetylpyridinium chloride (Sigma-Aldrich) was added to solubilize the nodules formed and the solution was maintained under agitation for $15 \mathrm{~min}$. After verifying the homogeneity of the solution, three aliquots of $100 \mu \mathrm{L}$ from each well were transferred to a 96-well plate (Costar Corp., Cambridge, MA, USA). Mineral nodule formation was evaluated in a manner proportional to the absorbance determined at $562 \mathrm{~nm}$ in an ELISA reader (Thermo Plate). The mean of the three aliquots was calculated, and the resultant data were used for statistical analysis $(n=8)$.

\section{Statistical analysis}

All the absorbance values were transformed into percentage considering the non-irradiated control group of each energy density as being $100 \%$. Then, irradiated and non-irradiated groups within each energy dose were compared using the Mann-Whitney statistical test. Then, because the absorbance values were transformed into percentage of the controls, the energy densities could be directly compared among them (irradiated cell groups) by the application of the Kruskal-Wallis test complemented by the Mann-Whitney test using the adjusted significance when the null hypothesis of equality among the groups was rejected. All the statistical inferences were considered at the level of significance of $5 \%$. The SPSS 23.0 software (IBM, Chicago, IL, USA) was used to perform the statistical analysis.

\section{Results}

\section{Cell viability analysis (MTT assay)}

The viability of the MDPC-23 cells irradiated with blue LED delivering different energy densities in comparison with nonirradiated cells may be observed in Fig. 1a. Irrespective of the energy density used to irradiate the cells, no effect on cell viability was detected. When the energy densities were compared among them, no statistically significant differences between the doses were observed either, with regard to biomodulation of cell viability (Fig. 1a).

\section{Total protein production}

Total protein production by MDPC-23 cells either irradiated with blue LED, or not, at different energy densities is presented in Fig. 1b. All the energy densities resulted in a significant
Fig. 1 a Viability, b total protein production, c alkaline phosphatase activity, $\mathbf{d}$ collagen synthesis, and $\mathbf{e}$ mineralized nodule deposition by MDPC-23 cells submitted to a single irradiation with blue LED delivering different energy densities $\left(\mathrm{J} / \mathrm{cm}^{2}\right)$. Boxes represent $50 \%$ of the data of each group. The bottom and top lines of each box represent the percentile 75 and percentile 25 , respectively, while the horizontal line inside the box represents the median, $n=8$. The maximum and minimum values of each group are represented by the brackets below and above the box, respectively. - - Within each energy density, groups connected by the asterisk are statistically different (Mann-Whitney, $p<0.05)$. ${ }^{\mathrm{a}}$ Letters allow comparisons among the energy densities for the irradiated groups. Groups represented by different letters are statistically different (MannWhitney, $p<0.05$ )

increase in total protein production. Although all the energy densities stimulated total protein production by the MDPC-23 cells, the highest values were obtained with irradiation at the doses of 0.5 and $2 \mathrm{~J} / \mathrm{cm}^{2}$, without difference between them (Fig. 1b).

\section{Alkaline phosphatase activity}

Analysis of alkaline phosphatase activity by the MDPC-23 cells in comparison with non-irradiated cells demonstrated that with the exception of the energy density of $0.5 \mathrm{~J} / \mathrm{cm}^{2}$, which did not differ from the control, all the other densities resulted in significant reduction in the activity of this protein (Fig. 1c). The greatest reduction was observed when the cells were irradiated with $15 \mathrm{~J} / \mathrm{cm}^{2}$, followed by the energy densities of 2, 4, and $10 \mathrm{~J} / \mathrm{cm}^{2}$, without difference among these latter densities (Fig. 1c).

\section{Collagen synthesis (Sircol red assay)}

Collagen synthesis by the MDPC-23 cells submitted to LED therapy at the selected parameters was significantly reduced (21\%) in comparison with the control when they received the ED of $10 \mathrm{~J} / \mathrm{cm}^{2}$, while all the other doses had no effect on this cell activity; that is, they were comparable with the control, in which the cells were not irradiated. When comparing the energy densities, $4 \mathrm{~J} / \mathrm{cm}^{2}$ presented the highest collagen production values (increase of $18 \%$ ), followed by the doses of 2 and $15 \mathrm{~J} / \mathrm{cm}^{2}$, without difference between them (Fig. 1d).

\section{Mineralization nodule formation (alizarin red test)}

Irradiation at the doses of 0.5 and $2 \mathrm{~J} / \mathrm{cm}^{2}$ resulted in a significant reduction in mineralization nodule formation in comparison with the control, while the dose of $15 \mathrm{~J} / \mathrm{cm}^{2}$ increased deposition of these nodules. The dose of $2 \mathrm{~J} / \mathrm{cm}^{2}$ resulted in the worst results, followed by the dose $0.5 \mathrm{~J} /$ $\mathrm{cm}^{2}$. The doses of 4,10 , and especially $15 \mathrm{~J} / \mathrm{cm}^{2}$ were the energy densities that least interfered with the deposition of mineralized nodules by MDPC-23 cells (Fig. 1e), which was positive in the case of $15 \mathrm{~J} / \mathrm{cm}^{2}$. 

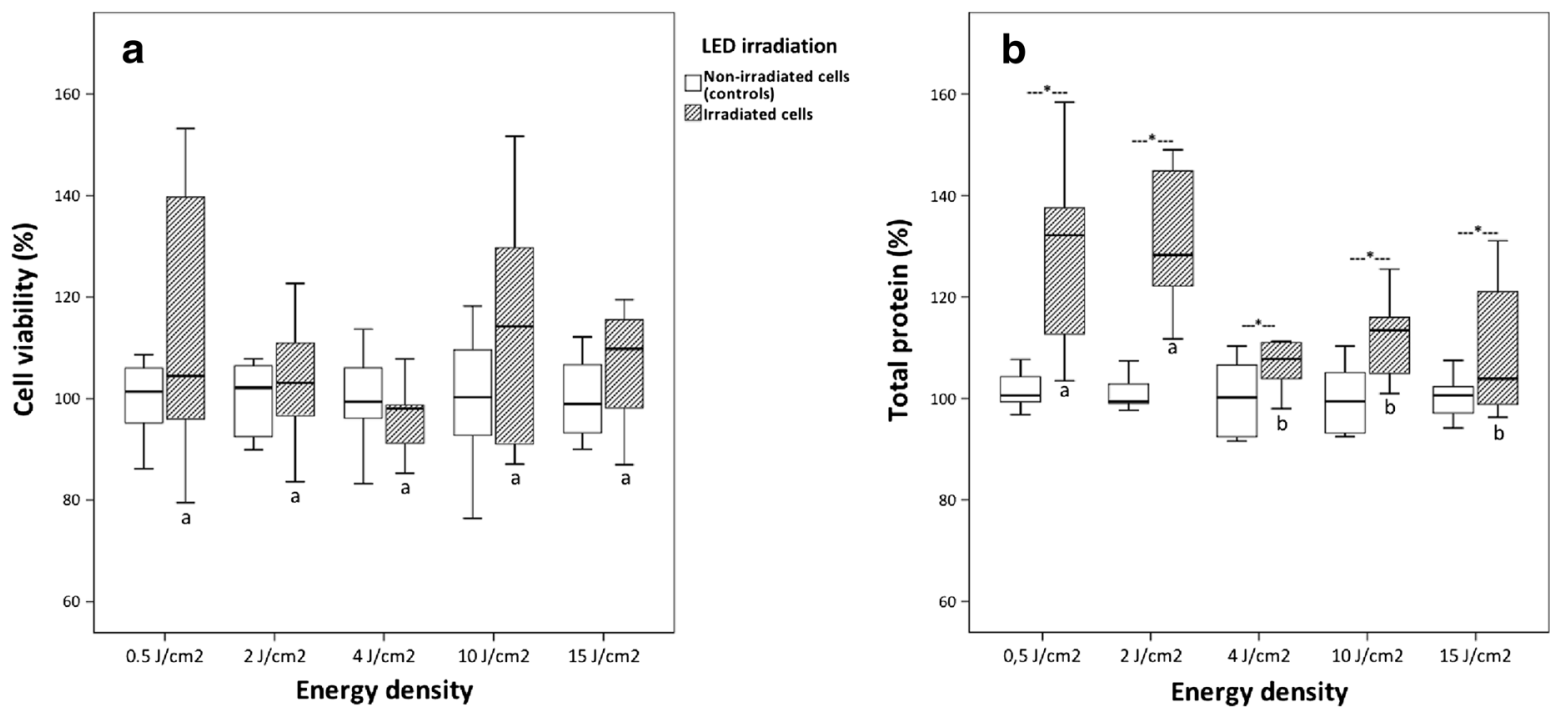

LED irradiation

$\square$ Non-irradiated cells

irradiated cells
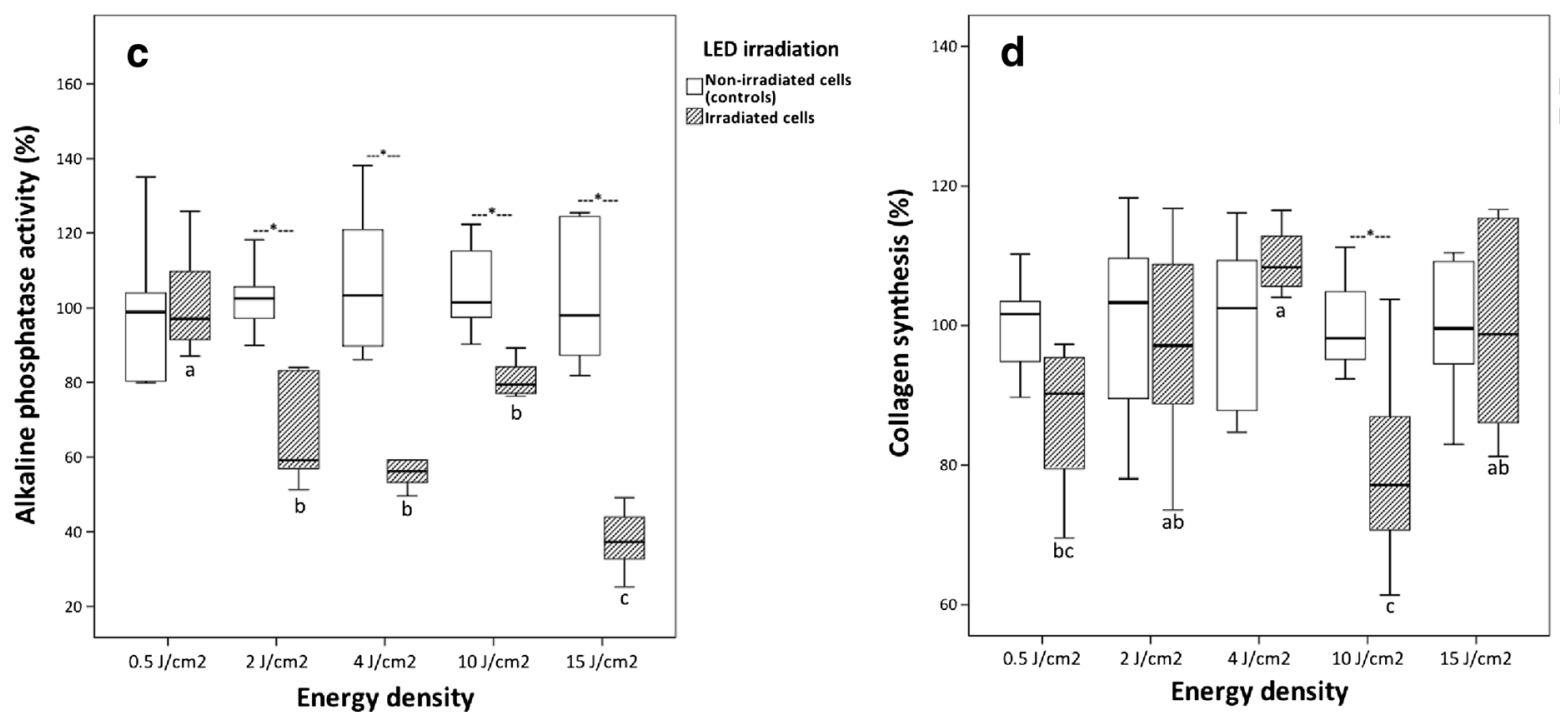

LED irradiation $\square$ (controls) Irradiated cells $\square$ Non-irradiated cells 㭗Irradiated cells

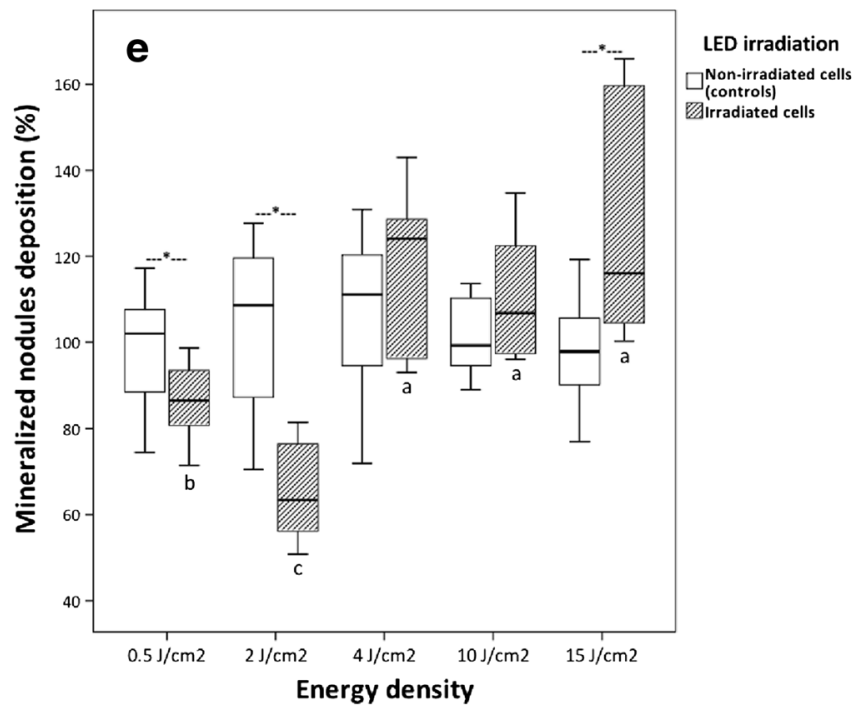




\section{Discussion}

The light generated by LEDs in the blue spectrum is routinely used for photoactivating resin-based dental materials. Although there are reports in the literature about the effects of this light on tissue functions [4, 29], only scanty data is found about the effects of blue LEDs on pulp cell metabolism [30]. The direct irradiation of cells with LED, as performed in the present study, intended to reproduce a clinical situation where the pulp tissue is exposed. On the other hand, in the study developed by Turrioni et al. [30], the authors evaluated the LED irradiation through a dentin barrier, simulating deep dentin cavities where the remaining dentin thickness is extremely thin (less than $0.5 \mathrm{~mm}$ ). In the present study, a range of energy densities from 0.5 to $15 \mathrm{~J} / \mathrm{cm}^{2}$ was used. Furthermore, the irradiance was lower $\left(20 \mathrm{~mW} / \mathrm{cm}^{2}\right)$ than the one used in the transdentinal study $\left(88 \mathrm{~mW} / \mathrm{cm}^{2}\right)$ [30] because cells were irradiated directly. However, since the irradiance was fixed, the higher the energy density, the longer the time needed to reach that density. The irradiation time varied from $21 \mathrm{~s}$ to deliver $0.5 \mathrm{~J} / \mathrm{cm}^{2}$ up to $12 \mathrm{~min}$ and $30 \mathrm{~s}$ for the energy dose of $15 \mathrm{~J} / \mathrm{cm}^{2}$. Although longer periods of irradiation would be clinically impractical, they were included as part of the screening process to find an energy dose capable of biostimulating the odontoblast-like cells. Further studies should also vary the irradiance. That was not performed in the present study due to limitations imposed by the irradiation device (LED table).

The energy densities used in this study were selected based on the results of some studies [6,11,12,18-24], although they all vary in terms of physical parameters, using wavelengths from $380-500$ to $855 \pm 20 \mathrm{~nm}$, irradiance at 550 and $40 \mathrm{~mW} /$ $\mathrm{cm}^{2}$, and energy densities ranging from 2 to $120 \mathrm{~J} / \mathrm{cm}^{2}$. Cell lineages also differed from the one used in this study. Some cell lineages investigated were normal human epidermal keratinocytes (NHEKs), oral squamous carcinoma cells (OSC2), Balb mouse fibroblasts (Balb), and primary cultures of primary teeth (HDPC) [19, 24]. As mentioned before, Turrioni et al. [30] evaluated the transdentinal photobiomodulation of odontoblast-like cells using different energy densities ( 4 and $25 \mathrm{~J} / \mathrm{cm}^{2}$ ), irradiance of $88 \mathrm{~mW} / \mathrm{cm}^{2}$, and LED at different wavelengths $(450,630$, and $840 \mathrm{~nm})$. The authors observed that the overall performance of the infrared and red LEDs was more effective than the blue LED. However, it was also seen that the blue LED $(450 \mathrm{~nm})$ delivered at the energy density of $4 \mathrm{~J} / \mathrm{cm}^{2}$ resulted in higher cell viability compared to the infrared LED $(840 \mathrm{~nm})$.

The cell viability results demonstrated that one single irradiation with blue LED did not influence the activity of the succinate dehydrogenase enzyme (SDH) in MDPC-23 odontoblast-like cells. As the purpose of using this light source would be right after the cavity preparation, or prior to a direct pulp capping or pulpotomy, it would be unfeasible to perform multiple irradiations. A triple irradiation was, however, capable of promoting an increase (10 to $20 \%$ ) in SDH activity for the cell lineages WI-38 and NHEK when compared with nonirradiated cells [31]. However, in the same study, other types of cells (Balb/c 3T3, HGF, MCF-7, and OSC-2) presented suppression of SDH activity, a fact that reinforced the concept of the specificity of the physical parameters for each cell lineage in particular.

Although the LED irradiation was not capable of increasing the cell viability, total protein production was increased after irradiation. That was true for all the energy densities, although the lower doses $\left(0.5\right.$ and $\left.2 \mathrm{~J} / \mathrm{cm}^{2}\right)$ were the most efficient. It is known that light absorption by cells varies according to the wavelength used for irradiation [32]. Wavelengths between 400 and $500 \mathrm{~nm}$ may positively affect tissues due to the elevated absorption of this wavelength by flavines [33, 34], whereas wavelengths higher than $500 \mathrm{~nm}$ are better absorbed by the cell cytochrome C-oxidase [35]. In the present research, the wavelength of $455 \mathrm{~nm}$ was used to irradiate MDPC-23 cells, which indicate that the blue light interacted directly with the flavines. However, when cells are irradiated by light in the spectrum below $500 \mathrm{~nm}$, depending on the physical parameters of the light source, the flavines may suffer photoreduction and thus trigger the formation of free radicals [33]. It is known that free radicals (oxygen reactive species) interfere in the metabolism or even cause irreversible cell damage [33]. That could explain the results obtained in the present study since the increase of protein production could be related to oxidative stress-induced proteins such as heat shock proteins rather than alkaline phosphatase and collagen $[12,36]$.

Alkaline phosphatase and type I collagen are essential proteins in dentin matrix formation and its subsequent mineralization. ALP is an enzyme expressed by cells that participate in the mineralization process, as is the case of odontoblast-like cells [37]. In spite of the increase in total protein production, the reduction or maintenance in alkaline phosphatase activity was observed in this study for all the EDs. Although using a different wavelength of the visible spectrum $(647 \mathrm{~nm})$, an increase in the activity of this enzyme was observed in the osteogenic activity of mesenchymal cells when irradiated with LED, at low energy densities of $0.093,0.279$, and $0.836 \mathrm{~J} / \mathrm{cm}^{2}$ [21]. However, in the mentioned study, the cells were maintained in an osteogenic medium and they were not submitted to nutritional restriction as were the cells in our study. Even in the face of this unfavorable condition, the MDPC-23 cells maintained their ALP activity when irradiated with the lowest ED of blue LED $\left(0.5 \mathrm{~J} / \mathrm{cm}^{2}\right)$.

Collagen production by the odontoblast-like cells was not affected by LED irradiation, with the exception of the dose of $10 \mathrm{~J} / \mathrm{cm}^{2}$, at which significant reduction in the production of this protein was seen. Since the presence of collagen and alkaline phosphatase is directly related to dentin matrix 
mineralization, the formation of mineralization nodules was also not biostimulated. Indeed, a reduced deposition of mineralized nodules was seen for the higher energy densities (10 and $15 \mathrm{~J} / \mathrm{cm}^{2}$ ), ratifying the fact that the increase in total protein is related to the synthesis of other proteins instead of the synthesis of collagen and ALP.

Overall, a single irradiation with blue LED light at the wavelength of $455 \mathrm{~nm}$ applied at distinct EDs on pulp cells in culture was not capable of increasing cell viability, ALP activity, or collagen synthesis. Therefore, the null hypothesis that odontoblast-like cells do not respond to the irradiation with blue LED producing more pulp repair-related proteins was not rejected. The lack of cell biostimulation, or even the inhibition of cell functions, was more clearly observed with the increase in EDs. As the increase in ED is directly related to the time of irradiation, it is possible to suggest that the longer the time of irradiation, the higher the level of free radical formation [12], which may have interfered negatively in the metabolism of the MDPC-23 cells.

\section{Conclusion}

According to the methodology used in this study, it was possible to conclude that a single irradiation with blue LED at the wavelength of $455 \mathrm{~nm}$, irradiance of $20 \mathrm{~mW} / \mathrm{cm}^{2}$, and energy densities ranging from 0.5 to $15 \mathrm{~J} / \mathrm{cm}^{2}$ does not have an effective capacity for the biostimulation of MDPC-23 odontoblastlike cells.

Acknowledgments The authors acknowledge the Fundação de Amparo à Pesquisa do Estado de São Paulo, FAPESP (grant 2012/ 08660-7), and the Conselho Nacional de Desenvolvimento Científico e Tecnológico, CNPq (grant 303599/2014-6), for the financial support.

\section{References}

1. Villa GEP, Catirse ABCEB, Lia RCC, Lizarelli RFZ (2007) In vivo analysis of low-power laser effects irradiation at stimulation of reactive dentine. Laser Phys Lett 4(9):690-695

2. Bergenholtz C (2000) Evidence for bacterial causation of adverse pulpal responses in resin-based dental restorations. Crit Rev Oral Biol Med 11(4):467-480

3. Costa CAS, Ribeiro AP, Giro EM, Randall RC, Hebling J (2011) Pulp response after application of two resin modified glass ionomer cements (RMGICs) in deep cavities of prepared human teeth. Dent Mater 27(7):158-170

4. DeLand MM, Weiss RA, McDaniel DH, Geronemus RG (2007) Treatment of radiation-induced dermatitis with lightemitting diode (LED) photomodulation. Lasers Surg Med 39(2):164-168

5. Machado AH, Pacheco Soares C, da Silva NS, Moraes KC (2009) Cellular and molecular studies of the initial process of the photodynamic therapy in Hep-2 cells using LED light source and two different photosensitizers. Cell Biol Int 33(7):785-795
6. Whelan HT, Smits RL Jr, Buchman EV, Whelan NT, Turner SG, Margolis DA, Cevenini V, Stinson H, Ignatius R, Martin T, Cwiklinski J, Philippi AF, Graf WR, Hodgson B, Gould L, Kane M, Chen G, Caviness J (2001) Effects of NASA light-emitting diode irradiation on wound healing. J Clin Laser Med Surg 19(6): 305-314

7. Weiss RA, McDaniel DH, Geronemus RG, Weiss MA, Beasley KL, Munavalli GM, Bellew SG (2005) Clinical experience with light-emitting diode (LED) photomodulation. Dermatol Surg 31(9):1199-1205

8. Huang PJ, Huang YC, Su MF, Yang TY, Huang JR, Jiang CP (2007) In vitro observations on the influence of copper peptide aids for the LED photoirradiation of fibroblast collagen synthesis. Photomed Laser Surg 25(3):183-190

9. Turrioni APS, Basso FG, Montoro LA, de Almeida LFD, de Souza Costa CA, Hebling J (2014) Phototherapy up-regulates dentin matrix proteins expression and synthesis by stem cells from humanexfoliated deciduous teeth. J Dent 42(10):1292-1299

10. Lewis JB, Wataha JC, Messer RLW, Caughman GB, Yamamoto T, Hsu SD (2004) Blue light differentially alters cellular redox properties. J Biomed Mater Res B Appl Biomater 72(2):223-229

11. Gritsch K, Ponsonnet L, Schembri C, Farge P, Pourreyron L, Grosgogeat B (2007) Biological behaviour of buccal cells exposed to blue light. Mater Sci Eng 28(5-6):805-810

12. Lockwood DB, Wataha JC, Lewis JB, Tseng WY, Messer RLW, Hsu SD (2005) Blue light generates reactive oxygen species (ROS) differentially in tumor vs. normal epithelial cells. Dent Mater 21(7): 683-688

13. Couve E, Osorio R, Schmachtenberg O (2013) The amazing odontoblast: activity, autophagy, and aging. J Dent Res 92(9):765-772

14. De Souza Costa CAS, Hebling J, Schelfel DL, Soares DGS, Basso FG, Ribeiro APD (2014) Methods to evaluate and strategies to improve the biocompatibility of dental materials and operative techniques. Dent Mater 30(7):769-784

15. Almeida-Lopes L, Rigau J, Zângaro RA, Guidugli-Neto J, Jaeger MMM (2001) Comparison of the low level laser therapy effects on cultured human gingival fibroblasts proliferation using different irradiance and same fluence. Lasers Surg Med 29(2):179-184

16. Stein A, Benayahu D, Maltz D, Oron U (2005) Low-level laser irradiation promotes proliferation and differentiation of human osteoblasts in vitro. Photomed Laser Surg 23(2):161-166

17. Alghamdi KM, Kumar A, Moussa NA (2012) Low-level laser therapy: a useful technique for enhancing the proliferation of various cultured cells. Lasers Med Sci 27(1):237-249

18. Vinck E, Cagnie B, Cornelissen MJ, Declercq HA, Cambier DC (2005) Green light emitting diode irradiation enhances fibroblast growth impaired by high glucose level. Photomed Laser Surg 23(2):167-171

19. Rotenberg S, Lewis JB, Lockwood PE, Tseng WY, Messer RLW, Hsu SD, Omata Y, Wataha JC (2006) Extracellular environment as one mediator of blue light-induced mitochondrial suppression. Dent Mater 22(8):759-764

20. Li WT, Chen HL, Wang CT (2006) Effect of light emitting diode irradiation on proliferation of human bone marrow mesenchymal stem cells. J Med Biol Eng 26(1):35-42

21. Kim HK, Kim JH, Abbas AA, Kim D, Park S, Chung JY, Song EK, Yoon TR (2009) Red light of $647 \mathrm{~nm}$ enhances osteogenic differentiation in mesenchymal stem cells. Lasers Med Sci 24(2):214 222

22. Li WT, Leu YC, Wu JL (2010) Red-light light-emitting diode irradiation increases the proliferation and osteogenic differentiation of rat bone marrow mesenchymal stem cells. Photomed Laser Surg 28(1):157-165

23. Ankri R, Friedman H, Savion N, Kotev-Emeth S, Breitbart H, Lubart R (2010) Visible light induces nitric oxide (NO) formation in sperm and endothelial cells. Lasers Surg Med 42(4):348-352 
24. Montoro LA, Turrioni AP, Basso FG, de Souza Costa CA, Hebling $\mathrm{J}$ (2014) Infrared LED irradiation photobiomodulation of oxidative stress in human dental pulp cells. Int Endod J 47(8):747-755

25. Read SM, Northcote DH (1981) Minimization of variation in the response to different proteins of the Coomassie blue $\mathrm{G}$ dye-binding assay for protein. Anal Biochem 116(1):53-64

26. Oliveira CF, Basso FG, Lins EC, Kurachi C, Hebling J, Bagnato VS, de Souza Costa CA (2010) Increased viability of odontoblastlike cells subjected to low-level laser irradiation. Laser Phys 20(7): 1659-1666

27. Oliveira CF, Basso FG, Lins EC, Kurachi C, Hebling J, Bagnato VS, de Souza Costa CA (2011) In vitro effect of low-level laser on odontoblast-like cells. Laser Phys Lett 8(2):155-163

28. Yang GC, Xu YH, Chen HX, Wang XJ (2015) Acute lymphoblastic leukemia cells inhibit the differentiation of bone mesenchymal stem cells into osteoblasts in vitro by activating notch signaling. Stem Cells Int 162410

29. Leal EC Jr, Lopes-Martins RA, Rossi RP, De Marchi T, Baroni BM, de Godoi V, Marcos RL, Ramos L, Bjordal JM (2009) Effect of cluster multi-diode light emitting diode therapy (LEDT) on exercise-induced skeletal muscle fatigue and skeletal muscle recovery in humans. Lasers Surg Med 41(8):572-577

30. Turrioni APS, Basso FG, Alonso JRL, de Oliveira CF, Hebling J, Bagnato VS, de Souza Costa CA (2015) Transdentinal cell photobiomodulation using different wavelengths. Oper Dent 40(1):102-111
31. Wataha JC, Lewis JB, Lockwood PE, Hsu S, Messer RL, Rueggeberg FA, Bouillaguet S (2004) Blue light differentially modulates cell survival and growth. J Dent Res 83(2):104-108

32. De Sousa APC, Santos JN, dos Reis JA, Ramos TA, de Souza J, Cangussú MCT, Pinheiro ALB (2010) Effect of LED phototherapy of three distinct wavelengths on fibroblasts on wound healing: a histological study in a rodent model. Photomed Laser Surg 28(4): 547-552

33. Eichler M, Lavi R, Shainberg A, Lubart R (2005) Flavins are source of visible-light-induced free radical formation in cells. Lasers Surg Med 37(4):314-319

34. Laloraya MM, Pradeep KG, Laloraya M (2009) Photochemical reaction sequences of blue light activated flavins: sensory transduction through free radical messengers. Biochem Mol Biol Int 33(3): 543-551

35. Karu TI, Pyatibrat LV, Kalendo GS (1995) Irradiation with He-Ne laser increases ATP level in cells cultivated in vitro. J Photochem Photobiol B 27(3):219-223

36. Bakthisaran R, Tangirala R, Rao CM (2015) Small heat shock proteins: role in cellular functions and pathology. Biochim Biophys Acta 1854(4):291-319

37. Butler WT, Ritchie H (1995) The nature and functional significance of dentin extracellular matrix proteins. Int J Dev Biol 39(1):169_ 179 